\title{
IMAGEN Y EDUCACIÓN: ALGUNAS IMPLICACIONES DIDÁCTICAS
}

\author{
Rocío Polanía Farfán \\ Docente Educación Artística y Cultural
}

El arte moderno puede cifrarse en estos versos de Antonin Artaud: "Nada de espectáculo representación - una obra debe cambiar cada noche -, es necesario que la obra cambie". Esa tendencia al cambio es la que lo sitúa entre los fenómenos sociales de transformación, de construcción progresiva, que deben insertarse en el fenómeno social más trascendente de control o liberación de los individuos de una nación: La Educación.

¿Es la Escuela del siglo XXI un espacio para una pedagogía capaz de asumir y de potenciar las capacidades de expresión de los estudiantes? ¿Se encuentra la educación impulsando el desarrollo de la creatividad y la puesta en juego de la totalidad de las capacidades expresivas que los niños y jóvenes poseen? ¿Son el arte y la educación una esperanza? El arte como proceso educativo, requiere de un aprendizaje que no puede limitarse a una simple habilidad técnica, sino que puede ampliarse hasta el punto de englobar la expresión de una visión particular o colectiva del mundo; es un instrumento de extensión de la percepción y de la conciencia humana.

En efecto, el desarrollo de la sensibilidad perceptiva debería, pues, convertirse en una de los componentes más importantes del proceso educativo. Pero, salvo en las artes, los sentidos parecen estar destinados a que se les ignore. Cuanto mayores sean las oportunidades para desarrollar la sensibilidad y la capacidad de agudizar todos los sentidos, mayor será también la oportunidad de aprender. Una educación a través del arte amplía el radio de acción de la educación de la mirada más allá de las formas, tomando partido por el equilibrio entre ética y estética.
La fusión del concepto de arte y el de educación a través de la Educación Artística ha venido demostrando a través del tiempo que resuelve, fortalece y enriquece los lenguajes visual y espacial tan predominantes en el cerebro humano, pues activa el hemisferio cerebral que la educación formal ha descuidado por haber ignorado los nuevos aportes de la neurología. Educación y arte articulan una unidad tan valiosa y significativa, que la enseñanza debe tratar, por lo tanto, de construir el entramado estructural del conocimiento a partir de las proposiciones que forman los conceptos. Estos, a la vez, expanden los significados.

La Educación Artística parte de una idea de arte amplia y general inscrita en los contenidos de cultura y fundamentada en una valoración sobre los procesos que dan lugar a los hechos artísticos. Se trata de una educación artística que entiende el arte como parte fundamental del conocimiento humano; esto significa que posee una estructura propia, inscrita en una más amplia del conocimiento general a la que no se opone sino que complementa.

En consecuencia, este trabajo intenta explorar la necesidad de reconocer la importancia del arte en los procesos educativos a través de La Educación Artística. Al respecto se abordarán los siguientes enunciados: El arte como expresión, La Educación Artística como un instrumento para la comprensión de la imagen, y El arte como comunicación, novedad y estrategia.

\section{EL ARTE COMO EXPRESIÓN}

El arte es una forma de conocimiento tan indispensable para el hombre como el mundo de la filosofía o de la ciencia. Desde luego, sólo si 
reconocemos claramente que el arte es una forma de conocimiento paralela a otras, pero distinta de ellas, por medio del cual el hombre llega a comprender y re-crear su mundo, podemos empezar a apreciar su importancia en la historia de la humanidad.

La historia humana inicia con la escritura y sin duda el arte la precede. Ha estado allí desde los albores de las primeras culturas y acompañará a las civilizaciones en las posteridades. Su importancia en la vida humana es incalculable. Por ende, la forma como se transmite la cultura, el conocimiento y el arte no tiene otro eje que la educación. Es ella la matriz renovadora de las formas de aprendizaje social que absorben las mentes para constituir lo que denominamos el andamiaje epistemológico y hermenéutico de la realidad fenoménica que los hombres perciben.

Ahora bien, si la educación es el eje, el arte por ser un fenómeno tan primario, revolucionario y evolucionarlo viene a ser el fundamento de esa estructura que denominaremos Educación Artística. Si consideramos al arte como lenguaje, se va esclareciendo el diálogo que sostiene con la Educación.

Comprendemos que un lenguaje humano es un sistema integrado por lo fonético-fonológico -que puede tener una expresión alfabética-, lo gramatical, lo semántico y lo pragmático. Cuando se habla de alfabetización para la interpretación de las imágenes, esta se queda regularmente en una abstracción. Por lo cual (se hace preciso convertir este lenguaje visual en verbal. Algo que de hecho el cerebro realiza, pero sin traducir o verter un lenguaje en el otro, de modo acertado y preciso.

En efecto, debido a que el objeto de la Educación Artística es el lenguaje de las imágenes, y pareciera que no estamos preparados para su lectura, este lenguaje se articula con lo representativo y con la comunicación lingüística, la lúdica, la estética y lo cognitivo. Por lo cual se establece que la mayor parte de la información del mundo nos entra por los distintos sentidos, lo cual se halla mediado por la representación, simbolización y abstracción conceptual que hacemos de las imágenes; por la manera como las organizamos o las ajustamos a nuestras emociones y concepciones del mundo, y por el modo como percibimos las imágenes y las ordenamos en jerarquías conforme a las asociaciones de placer, dolor, tragedia, humor, etc. Por último, una mediación basada en la gradación de la innovación que nos permite relacionar conceptos, explicarlos, reinterpretarlos y reconceptualizarlos.

Estudiar una imagen, por lo tanto, implica obtener una información completa de la organización estética de los objetos insertos en ella. Habría aún que contemplar la vaguedad nocional de nuestro propio punto de vista. Pero especialmente abordar este lenguaje llevaría a evaluar o mejor reconocer la novedad expresa en esa imagen, aquello que la hace tan diferente a las millones de imágenes que bombardean el campo visual. Este alfabeto de la imagen estaría pues en relación directa con la inserción de la creatividad como método en la educación, pues el arte es portador de creatividad; pero en igual medida leer el arte es una actividad creativa.

Al respecto, Ernesto Sábato sostenía que el arte no puede prescindir del yo de manera similar a como lo hace la ciencia y que esa era la virtud del arte. Ello significa que educar sin arte equivaldría a desconocer el yo que la misma educación debe afirmar como constructo de la personalidad misma, amenazada de diluirse como masa anodina en el concierto bullicioso del anonimato de millones de individuos. A esto se debe que la Educación Artística, probada su inminente e incesante importancia como disciplina, deba ir más allá de las leyes de las formas y hacer lo que ha hecho desde la aparición del hombre en el cuaternario: instaurar las leyes de la existencia humana.

La necesidad del arte en la educación no puede demostrarse sin preguntarse capciosamente: ¿Y qué es el arte? A esta pregunta no dejan de contestar el hombre vulgar y el aficionado, con la seguridad de que no se equivocan y de que se trata de cosas perfectamente claras. Podríamos, sin embargo, en esta dirección inquirir: ¿No hay en arquitectura edificios que no son obras de arte y otros que, con pretensiones artísticas, no alcanzan el apelativo de bellos y resultan desagradables a la vista, y por lo tanto no pueden ser considerados como obras de arte? ¿No ocurre lo mismo en escultura, en música y en poesía? ¿Dónde residen entonces las señales características de las obras de arte? 
El arte, en todas sus formas, se halla limitado, de un lado por la utilidad práctica, del otro por las categorías estéticas de lo bello y lo feo, 0 de lo sublime y lo común. Entonces, ¿Cómo se distinguirán esas dos cosas que le limitan? A tal pregunta, el hombre profano de una sociedad que se llama así misma cultivada y el propio artista si no ha profundizado en el fenómeno de lo estético, tienen una respuesta preparada. Quizá contestarán que esa pregunta se formuló hace mucho tiempo, y que nadie debe ignorarla. ¿El arte?, afirmarán, es una actividad que produce la belleza.

Pero si en esto consiste el arte, ¿son obras de arte el baile de un tango o una opereta? El hombre culto y el artista contestarán aún, pero ya con cierta vacilación: Sl; un buen baile y una linda opereta también son arte, pues equivalen a manifestaciones de la belleza.

El arte es la expresión de una vida razonable y consciente, que evoca en nosotros a la vez la conciencia más profunda de nuestra existencia y los más altos sentimientos y pensamientos más nobles, pero es también capaz de mostrar nuestras monstruosidades. Al parecer, el arte transporta al hombre desde la vida personal a la vida universal por medio de una participación de los mismos sentimientos y de las mismas ideas. Ese transporte de la vida personal a la universal es la fuerza que transvasa al arte en la educación. En ese transvasar ya no existe una complementariedad sino una unidad sólida e indisoluble.

Según Cherbuliez (citado por Tolstoy), el arte es una actividad que: $1^{\circ}$ satisface nuestro amor innato por las apariencias; $2^{0}$ encarna, en esas mismas apariencias, ideas; y $3^{0}$ da al mismo tiempo placer a nuestros sentidos, a nuestro corazón y a nuestra razón'. No obstante, si el arte satisface nuestras apariencias, también satisface nuestro amor por lo oculto, lo que hay detrás de la apariencia, la epifanía misma. Justamente de esa dualidad primigenia encarnan las ideas sobre las mismas apariencias y lo que pensamos 0 creemos que es la realidad. En este punto de confrontación entre la apariencia, la idea y la razón es cuando el arte se acerca a la ciencia, cuando permite intuir lo que la ciencia no puede probar ni predecir.

Herbert Read en su tesis original lleva a identificar el arte y la educación en un mismo y único fin. Está convencido con absoluta certeza de este hecho al afirmar: "... Ia finalidad del arte es la educación, que debería ser idéntica a la finalidad de la educación misma" 2. Al respecto, Read considera que la educación ha padecido una tendencia exagerada, no conveniente, hacia el pensamiento lógico, "incapaz de actividad imaginativa y pensamiento sensorial". Le suma además a esta 'aberración' de nuestros sistemas educativos tradicionales, el "hábito de establecer territorios separados y fronteras inviolables", contrariando la estructura orgánica, integradora de nuestra mente y nuestra sociedad.

Así mismo, Read afirma que "...la concepción aceptada de la educación como colección de materias en competencia, enseñadas por especialistas separados en aulas separadas, es tan grotesca que no puede responder a principio alguno de organización, sino solo a la acumulación caótica de un proceso histórico no dirigido" ${ }^{3}$ El argumento de Read resulta sumamente poderoso e irrefutable. De hecho, infinidad de teóricos influyentes en las ciencias han corroborado sus posturas basándose en la estructura del cerebro a nivel experimental.

En esta línea, Howard Gardner, por ejemplo, en su libro Educación artística y desarrollo humano, afirma, concediéndole la razón de sus propuestas a Read, que: "En el trabajo llevado a cabo con mis colegas durante los últimos años...se encuentran pruebas convincentes que los estudiantes aprenden de manera eficaz....cuando su aprendizaje artístico está anclado en la producción artística; cuando hay un intercambio fácil entre las diversas formas de conocimiento, incluyendo las formas intuitivas, artesanales, simbólicas y notacionales; y cuando los estudiantes gozan de una holgada oportunidad para reflexionar sobre su progreso"'.

1-TOLSTOY, Leon. Qué es el arte? Segunda edición cibernética. Agosto de 2002

2- Read, Herbert. Educación por el arte. Ediciones Paidos Ibérica, colección: Paidos Educador. Traducción de Luis Fabricant, primera reimpresión 1982, Barcelona; p. 119

3- Mitchell, W. J. T. Showingseeing: A critique of visual culture. In N. Mirzoeff (Ed.), The visual culture reader (pp. 86-101). London; New York: Roudedge. 1998. Pág. 119

4- GADNER, Howard, Educación Artística y desarrollo humano. Ed. Paidos. Barcelona. Pág. 88 
Por lo tanto el aprendizaje del arte debe ser una respuesta a las realidades contemporáneas, lo que significa ajustarse a los intereses que poseen los estudiantes y a los contextos en donde se desarrollan, para de esta manera cautivar su atención y así realizar un aprendizaje más significativo. Esto supone un cambio en las prácticas pedagógicas de los docentes, las cuales deben apuntar a facilitar y revelar, efectivamente, el compromiso crítico con la experiencia del ver. En palabras de W.J.T. Mitchell se trata de luchar para "superar el velo de la familiaridad y la auto-evidencia de que rodea la experiencia de ver...para hacer ver a mostrarse, por decirlo en la pantalla, y hacerla accesible al análisis"5.

Desde esta perspectiva, y teniendo en cuenta que el dominio de la educación artística contemporánea es la cultura visual, se abren espacios educativos donde las capas socioculturales, la complejidad política, estética, histórica y pedagógica que rodea no sólo las obras de arte sino la producción de imágenes en general, puedan ser examinadas y exploradas bajo una mirada crítica y reflexiva. No se trata de formar a niños y jóvenes como consumidores pasivos, sino de encontrar estrategias que impliquen conocer y comprender las imágenes, y confrontar a los estudiantes con ellas en relación con la cultura y el contexto que desee comprender.

En este sentido la concepción de aprendizajeenseñanza en artes no sólo debe tener en cuenta las obras canónicas, sino la incorporación en el aula de conocimientos provenientes de otras áreas como el cine, la televisión, el teatro, los videojuegos, la moda, y la cultura popular, entre otros. Las artes como estrategia pedagógica para la comprensión de la cultura visual, se sitúan en la tarea de mover a los estudiantes a los espacios de toma de conciencia y resistencia frente a aquellos espacios que los presionan a permanecer en la indiferencia en la cual se encuentran inmersos. Los educadores artísticos deben empezar a desafiar a los estudiantes, a reconsiderar la complejidad de las experiencias visuales diarias, llevándolos a una "meditación sobre la ceguera, lo invisible, lo oculto, lo invisible, y lo que pasa por alto".
En este contexto se hace necesario y urgente, si se quiere tener en nuestros países personas con mejores oportunidades y mejores personas con calidad de vida, ceder el paso a una educación más integral, más dinámica, más ecléctica u holística, como lo es la Educación Artística, la cual incluye formas conscientes y críticas de intervención sociocultural de los sitios estéticos cotidianos en los cuales se desenvuelven los estudiantes.

En el sentido educativo, el arte se entiende como una actividad humana consciente en la que el individuo se manifiesta plenamente capaz de observar e intervenir su contexto. Como resultado de esta participa, experimenta y explora ideas, materias y materiales, configura imaginarios y formas innovadoramente propicia conexiones creativas y críticas entre morfologías, sentimientos y conocimientos.

\section{LA EDUCACIÓN ARTÍSTICA COMO UN INSTRUMENTO PARA LA COMPRENSIÓN DE LA IMAGEN.}

De acuerdo a Read el arte ampliamente concebido debería ser la base fundamental de la educación. Pues ningún otro campo del conocimiento puede dar al niño o joven no solo una conciencia en la cual se hallan correlacionados y unificados imagen y concepto, sensación y pensamiento, sino también, al mismo tiempo, un conocimiento instintivo de las leyes del universo y un hábito o comportamiento en armonía con la naturaleza"7 y la existencia.

La vinculación del arte, la vida y la naturaleza es patente en el mundo de la vida, aunque se torne invisible en la maraña de los seres y las cosas. Contemplar buenos cuadros, oír las mejores obras musicales o visitar monumentos arquitectónicos no constituyen una vía suficiente para una auténtica formación artística, pero contribuyen a ella en la medida en que esas cosas percibidas puedan ser vistas y observadas, leídas y escritas como imágenes. Es decir, la percepción visual se convierte en un instrumento de transmisión que propicia la conceptualización y los elementos del lenguaje propio de la sintaxis de las imágenes.

5 - Pag. 86

6 - lbidem, pág 90

7- READ. Herbert. Educación por el arte. Ediciones Paidos. Barcelona. 1982, p. 89 
Pero, ¿cómo leer una imagen? Una imagen se lee con la $A$ de armonía, la B de Bisección, la $C$ de captura, la $D$ de demolición. Aquí se vincula la creatividad de la naturaleza con la creatividad de la percepción y la comprensión, es decir, la manera como lamente humana construye, deconstruye y reconstruye mundos posibles.

Entender la educación artísticasupone también un acto cultural de aproximación a la propia cultura. "La cultura es el vehículo mediante el cual los niños y jóvenes adquieren los conceptos que han sido construidos a lo largo de los siglos". comprobado, el significado del término cultura está sometido a un continuo y serio debate que implica una realidad mucho más amplia que la relativa al patrimonio artístico. La cultura, asegura Geertz, (1990), no es una realidad, algo a lo que puedan atribuirse de manera casual acontecimientos sociales, modos de conducta, instituciones o procesos sociales. Comprender la cultura de un pueblo supone captar su carácter normal sin reducir sus particularidades.

La cultura se constituye en estructuras de significación en virtud de las cuales los hombres dan forma a su experiencia. Esa experiencia formal desde las particularidades del hecho artístico deviene inminentemente en un acto cultural extendido a la experiencia humana, plasmada en los fenómenos artísticos como otra forma subyacente a la mente humana de comprender el mundo. Este mundo manifestado por el arte se torna esclarecido en la mente de los niños y los jóvenes, por contener los elementos de sus mundos fantásticos y la manera interrogadora con que ellos confrontan la realidad que ante sus ojos se revela extraña e inquietante.

Decía Ortega y Gasset (1981): "La vida humana es una realidad extraña, de la cual lo primero que conviene decir es que es la realidad radical, en el sentido de que a ella tenemos que referir todas las demás, ya que las demás realidades, efectivas 0 presuntas, tienen de uno u otro modo que aparecer en ella. ${ }^{\prime 9}$ En efecto, extrañar el mundo es una de las particularidades del arte, y ese extrañamiento es lo que relaciona efectivamente al arte con la educación, ya que este acontecimiento es el que la vuelve atractiva para el niño y el joven.

La realidad es radical porque es la raíz de sus derivados, es decir el referente básico para construir las realidades, y en ese sentido el arte se transforma en una herramienta educativa para cultivar la sensibilidad, puesto que crea realidades a partir de una fundamental 0 nocional, aproximándose al pensamiento nocional del niño 0 al conceptual y formal del joven. Es decir, que el arte proporciona la extensión de la percepción al proyectar realidades diversas, y otro camino de interpretar y comprender el mundo, a lo que añade la facultad de reestructurar las realidades que se le presentan activando así la capacidad creadora.

Eisner Elliot en su libro, Educar la visión artística, afirma que para Lowenfeld "el arte es una herramienta educativa que puede cultivar la sensibilidad del hombre, fomentar la cooperación, reducir el egoísmo $\mathrm{y}$, por encima de todo, desarrollar una capacidad general de funcionamiento creativo"10. Según Lowenfeld el arte se convierte en un mecanismo de mejoramiento de la convivencia ciudadana, de la participación democrática y de la generación de la creatividad en niños y jóvenes; estas son razones de peso para incluir al arte en los procesos educativos.

Siguiendo a Eisner el arte cumple tres funciones principales: "Una es ofrecer un sentido de lo visionario en la experiencia humana, es decir, que el arte es capaz de hacer visible a través de la imagen las expresiones sublimes 0 trascendentes del hombre. Dos, funciona como un modo de activar la sensibilidad con el objeto de ejercitar potencialidades, habilidades y destrezas. $Y$ tres, la capacidad de vivificar lo concreto, o sea el poder articular la visión que se tiene, se ofrece 0 se presenta en la realidad del observador y el de poder capturar el momento, evento que permite una nueva contemplación de la visión o de la realidad misma"11. Una cuarta función del arte que puede añadirse sería la de proporcionar a la percepción una fórmula para esencializar la vida y, en gran medida, para poder valorarla.

8 - NOVAK, Joseph D. y GOWIN, D. Bob. Aprendiendo a Aprender, Barcelona: Ediciones Martínez Roca, SA, 1988. Fotocopias

9 - ORTEGA Y GASSSET, José. ideas y Creencias. 1955. Revista Píxel- Bit

10 - EISNER, Elliot. Educar la visión art/stica. Ed. Paidos. Barcelona, 1998.

11 - Ibldem, p.9, 10 
Abandonar la idea del individuo que percibe como una "tabula rasa" para caracterizarlo como sujeto activo que, consciente 0 inconscientemente, selecciona lo que percibe, jerarquiza la información y otorga significaciones de acuerdo con las experiencias previas y el contexto sociocultural, exige la reconfiguración de los sentidos, donde la totalidad posee atributos que la suma de las partes no presenta, no es natural sino cultural, e implica un proceso en el cual intervienen las capacidades sensoriales, cognitivas y representativas que, por tanto, pueden enseñarse, aprenderse, evaluarse y constituirse en contenidos curriculares para todos los programas de formación artística.

La Educación Artística permite sentir, explorar, conocer y transformar la realidad a la vez que facilita el desarrollo integral y armónico de las cualidades humanas. La presencia del arte en la educación favorece la comprensión y expresión de la belleza. Su propósito, por tanto, es el desarrollo de la sensibilidad estética, el despertar de los procesos creadores y la ampliación de los potenciales personales, posibilitando profundizar en el papel del arte como una esencial e irrenunciable forma de conocimiento. El área favorece la percepción activa de las cualidades sonoras (duración, intensidad, altura y timbre), de las características visuales (formas, colores, líneas, texturas, luz o movimientos) y kinestésicos (olores, sabores, texturas, movimientos corporales) presentes en los espacios naturales, en las obras artísticas y en las creaciones humanas. Saber orientarse mediante los sonidos o poder navegar al contemplar las estrellas son muestras de cómo el desarrollo de la escucha o la mirada atenta pueden convertirse en habilidades útiles para la vida de los seres humanos.

La iniciación sensible visual, sonora 0 kinestésica pone en contacto al observador con el mundo desde la contemplación de su belleza. La Educación Artística, se sirve entonces del medio como fuente para la creación artística al explorar, manipular e incorporar a las obras las inspiraciones y recursos creativos que le proporciona.

Sin embargo el aprendizaje de los lenguajes artísticos de los cuales se sirve la educación artística en sus dimensiones sonora, sintáctica, semántica y pragmá- tica contribuye a alcanzar competencias complejas que permiten desarrollar la capacidad de abstracción, la construcción de un pensamiento crítico y divergente, la apropiación de significados y valores culturales, y la elaboración y comprensión de mensajes significativos. Considerar la realidad circundante contemplando contextos culturales e históricos y logrando una interpretación simbólica de la misma favorece una participación social activa, plenay autónoma.

En este sentido el tratamiento de cuestiones tales como la espacialidad, la temporalidad, el esquema corporal, el desarrollo de la memoria, la coordinación psicomotriz, la percepción, la elaboración de marcos conceptuales acerca de las nociones de simetría, asimetría, ritmo, repetición, céntrico, excéntrico, tensión, distensión, entre otras, se constituyen en cuestiones esenciales de la Educación Artística, donde la relación entre obra, sujeto y contexto se encuentra privilegiada. El arte, como lenguaje, permite el acercamiento, en profundizaciones sucesivas, a niveles de apropiación de elementos que posibilitan a los estudiantes producir e interpretar comprendiendo. La internalización de los lenguajes artísticos implica la comprensión de modos de organización que dan cuenta de diversas lógicas internas en la manifestación artística.

Si bien la función de la Educación Artística en el sistema educativo no consiste en la formación de artistas, el conocimiento de las técnicas, los recursos y elementos formales y su organización, la posibilidad de expresarse y la voluntad comunicativa cobran especial interés en tanto se orienten a la producción de sentido y a la comprensión, más allá de lo literal, de los diferentes discursos propios del hombre. Por lo tanto los educadores implicados en los procesos de la Educación Artística deben ser capaces de orientar los aprendizajes apostando por la perspectiva de la Educación para la Comprensión, cuya función no sólo radica en trasmitir contenidos, sino también en facilitar la construcción de la subjetividad de manera que aprendan estrategias y recursos para interpretar (críticamente) el mundo en el cual viven, en especial el universo de las imágenes ${ }^{12}$.

En el ámbito escolar comprender el arte no sería, por tanto decodificar, es decir, desentrañar algunos

12 - AGUIRRE, Imanol. Teorías y prácticas en educación artística. Octaedro -EUB. Navarra, 2005, pág. 332 
significados preexistentes en el hecho 0 producto artístico. Por el contrario comprender consistiría en apropiarse de estos condensados simbólicos para utilizarlos en los proyectos identitarios. Desde el punto de vista educativo, en consecuencia, el interés en la comprensión artística no reside tanto en su eficacia para proporcionar conocimientos sobre el "otro productor", como en su poder para configurar identidad y desarrollar sensibilidad estética, transformado las experiencias emotivas ajenas en tomas de conciencia sobre la propia existencia ${ }^{13}$.

En palabras de Efland. Freedman y Stuahr la función de la enseñanza de la Educación Artística "es preparar a los estudiantes para comprender los mundos sociales y culturales en los que ellos habitan. Esos mundos son representaciones creadas con las cualidades estéticas de los medios ${ }^{114}$. Por lo tanto comprender no significa develar verdades ocultas en los mensajes artísticos, ni transformar debería ser entendido como provocar un cambio social como consecuencia de la develación de tales verdades. Frente a esta idea la acción educativa debería encaminarse a:

- "Primar en buscar y cultivar la experiencia estética en nuestras transacciones con el arte, recordándonos que la experiencia es en última instancia aquello sobre lo que trata el arte.

- Ayudarnos a conocer y valorar esas formas que nos proporcionan experiencias estéticas y que podrían hacerlo más y mejor si pudieran ser apreciadas y cultivadas como formas legítimas del arte.

- En definitiva, lo importante es que las obras de arte tengan poder performativo, capacidad de engarzarse con cada biografía, ser experimentadas estéticamente e integrarse así en cada experiencia vital, contribuyendo a la creación de "sí mismo." A nuestro juicio, este es el único carácter transformador que puede tener el arte y la educación artística y para lograrlo no importa demasiado si el producto de partida forma parte de lo legitimado 0 del arte popular"15.

La nueva perspectiva sobre la Educación Artística supone concebir el currículo como un proceso creativo y un espacio conceptual en el cual los estudiantes desarrollan sus ideas con la ayuda de los educadores, quienes no actúan meramente como guías sino como compañeros críticos. El currículo está volviendo a ser entendido como una forma de mediación entre estudiantes, profesores, y un amplio rango de textos e imágenes procedentes tanto del interior como del exterior de la Escuela. El cambio actual centra la atención sobre la compleja y crítica interacción entre el hacer y el ver, la cual está en las raíces del aprendizaje en y a través de las artes visuales $^{16}$.

Hoy debiera ser una prioridad educativa educar en la Cultura Visual (que es el nuevo campo, mucho más rico e interdisciplinar en el que debe encuadrarse la Educación Artística actual y que tiene que ver no sólo con la producción de imágenes, sino además con su análisis, contextualización, construcción de narrativas y de significados...). Como afirma Freedman, hoy no podemos entender la imagen sólo desde lo expresivo 0 desde un análisis formal ${ }^{17}$. Con ello se hace más reveladora la afirmación de Nicholas Mirzoeff cuando dice: "Ver no es creer, sino interpretar. Las imágenes visuales tienen éxito o fracasan en la medida en las que podemos interpretarlas satisfactoriamente" ${ }^{18}$.

Si el mundo está lleno de imágenes y el campo visual recibe la mayor parte de información del mundo, no cabe la menor duda que se hace preciso adquirir habilidades para verlas y observarlas, pero si las vemos, también debemos leerlas, escribirlas, pero sobre manera, hablar de las imágenes y sobre las imágenes que constituyen el mundo.

Para tal fin se hace evidente la necesidad de una metodología que permita obtener estas habilidades lectoras, escritoras y parlantes para ser dueños de esas imágenes, controlarlas o beneficiarnos de ellas, ya sea por el gozo o para el uso. Ello se logra si se quiere sintetizar accediendo a un proceso consciente

13 - Ibìd. pág. 332

14 - Ibid, pág 329

15 - Ibid. Pág 329-330

16 - FREEDMAN, Kerry Enseñando Cultura Visual:Educación artística y la formación de Identidad.

http://www.ub.es/boletineducart/boletineducart/info/freedman.htm.

17 - FREEDMAN, K. "Kerry Freedman y la pedagogíaestética". Pamplona. Boletín Informativo de la Universidad Pública de Navarra, Comunicaciones No. 38,1999

18 - Mirzoeff, Nicholas. Introducción a la cultura visual Barcelona, Ed. Paldos, (2003) 
de reconstrucción de la realidad. Pero para lograr dicha reconstrucción hará falta que el veedorobservador empiece su lectura organizando la realidad, siempre y cuando esta llegue a elaborarse desde la representación directa que se suele hacer de la realidad. Esas representaciones convierten al arte en un fenómeno de comunicación que carecía de audiencia, de auditores y locutores.

Si se logra como implicación didáctica de la Educación Artística hacer un paralelo ilustrador de la metáfora lingüística con la visual están ganadas las primeras letras del alfabeto visual. En efecto, puede representarse una estructura con dos líneas y un punto, como se puede representar una realidad objetual o procesual con una 0 dos palabras y una pausa.

En otras palabras la metodología analógica se convierte en una "piedra angular" en la Educación Artística, puesto que la analogía es la base de casi todas las transferencias cognitivas. Podría decirse que se necesitaría empezar a pensar con los ojos. El por qué ha quedado expuesto centrado en el campo visual, pero agréguese ahora la duración de la imagen para comprobar su importancia y la necesidad inminente del alfabeto y metáfora de la imagen: a las palabras se las lleva el viento; la imagen, buena o mala, perdura. En ese estadio entra triunfal el arte, ahora ostentando el nuevo perfil de la educación y hace la pregunta del buen maestro: ¿Ser joven hoy no consiste en redescubrir a Velásquez, Poussin o Ingres? Entendiéndose que son metonimias tan visibles en las imágenes que abstraen y muestran al autor en la obra 0 a la parte en el todo.

Y tratándose de lectura visual con sus tropos, no se trata de aprender a leer una imagen (como identificación de elementos visuales aislados), sino de conocer críticamente las diferentes manifestaciones artísticas de cada cultura (y no sólo las obras de arte definidas como tales por la alta cultura de Occidente y recogidas en sus museos y enciclopedias)... Conocer... (para plasmar) como forma de interpretación ${ }^{\text {"19}}$.

Entonces, la Cultura visual encuentra especial sentido en una educación integral, que parte de la realidad y forma al estudiante como una persona capaz de adaptarse a su medio, pero de manera crítica. Se convierte entonces en una herramienta para construirse, desde la trayectoria vital, desde la propia biografía, desde nuestros imaginarios.

\section{EL ARTE COMO COMUNICACIÓN, NOVEDAD Y ESTRATEGIA}

No todo es negativo en la comunicación visual, la captación y el mantenimiento de la atención, el interés que despierta por su atractivo, la facilidad de la comprensión, la posibilidad de creación y expresión, el acercamiento a las realidades o ficciones lejanas o inaccesibles, así como la adaptación al progreso y al medio social. Hoy, por el contrario, se hace crucial positivar la cultura de la imagen para construir una estética científica.

La estética era femenina hasta que las cuestiones y experiencias de lo bello adquirieron otra sensibilidad en el arte. Ello se debe a que la nueva estética se arraiga a la vida como un joven alocado poniendo en peligro su vida para vivirla. Es por ello que el lenguaje verbal-visual surge, se mantiene y se comunica en un ambiente de vida.

¿Qué formas serán comunicables entre los contemporáneos y sus descendientes sin perder la capacidad de proporcionar modos de vida válidos y sin anquilosamientos? Mantener, con vigor en las mismas creaciones e interpretaciones artísticas y culturales de todo tipo, su fuerza creadora y libre será el primer paso para poner de manifiesto su entronque natural 0 su alejamiento de lo indudablemente real. Bajo esta mirada la imagen como comunicación se encuentra en sinergia con los ámbitos cognitivos y emotivos; de por sí la comunicación visual es un acto cognitivo y emotivo al mismo tiempo, pues como dice R. Arnheim, la percepción visual generaliza y diferencia simultáneamente. Se trata de revalorar la emoción, el sentimiento y la expresión que hasta hace poco se habían tenido como reacciones irracionales, poco fiables para el conocimiento; por esto la educación no se ha apoyado en la interacción de la intuición con el intelecto, la imagen con el concepto, la imaginación con la razón.

La sensación estética y la realización artística penetran esclareciendo la naturaleza, como conciencia

19 - HERNANDEZ, Fernando. "Educación y Cultura visual". Barcelona. Octaedro. Año 2000. pág 87 
explicativa no abstraíbie, y dan lugar a la acción imaginativa más poderosa y diversa. Necesitamos alcanzar una comprensión más intensa y diversa de la imaginación, que despierte la sensación estética y la realización artística en modos de vida, en potenciación de las situaciones humanas aun con el riesgo de novedad; como la plasmación huidiza más íntima y vinculada a las aspiraciones genuinas de la vida humana. La invención de modos de vida hermosos, el arte de vivir como meta de la educación artística, en su mejor expresión, llenará de sentido toda creación y contemplación de las artes plásticas y de las artes temporales.

En lo que respecta al riesgo de la novedad y siguiendo a Imanol Aguirre (2005), la novedad como estrategia didáctica, su detección, su gradación, sus clases, sus orígenes y efectos son estadios clave en los sucesos creativos. Debido a que la novedad está sujeta a gradación puede contemplarse la secuencia de aquello que ha transformado una pequeña parte de su ser anterior en una creatividad que puede vincularse a las más altas cotas de novedad.

Por otra parte, en la creatividad existen varias clases de novedad cualitativamente diferentes: la novedad que afecta a la forma, al método, al modelo o al estilo, afecta de diferente forma al hecho creativo. De igual forma, la novedad lograda por personas creativas tiene varios orígenes detectables en las personas expuestas al arte (educación artística): puede ser intencionada, azarosa, deliberada, espontánea, metódica, etc. Cada una de ellas constituye el sello de las diversas actitudes de las personas creativas y la expresión de sus destrezas, mentalidades y talentos.

Por último, la innovación tiene efectos diferentes: desde los neutros hasta los que conmueven a individuos, a amplios grupos humanos 0 a la humanidad misma. Ejemplos existen a montón como el Guernica de Picasso 0 El grito de Munch o los murales Mexicanos Pero cualquier ser humano expuesto a la educación artística puede mostrar estos signos de novedad, con un discurso, una ética intachable 0 un modelo del ADN llevado a la abstracción de lo que implica el retorcimiento de la pobreza y la superpoblación.

La ecuación de la Educación Artística se ejecuta en la creatividad, siendo desarrollada por el hemisferio dionisiaco del campo neuronal humano; como lo expone Herbert Read al acusar a la educación logicista, la cual ha obstaculizado la actividad imaginativa y el pensamiento sensorial. El mismo cerebro trabaja holísticamente, pero la educación tradicional se empeña en establecer fronteras y divisiones del conocimiento. Cosa que, por el contrario, lleva a feliz término neuronal la Educación Artística.

En esa vía, comprendemos que la actividad artística se expresa en lo dionisiaco, lo lúdico, lo riesgoso, lo novedoso, la danza, el canto. Lo dionisiaco propuesto aquí como estrategia didáctica, que expresa arte y vida en la naturaleza, es fuerza creadora libre y clasificadora a la vez. Por todo ello, no es el valor máximo de la forma estética su recreabilidad, sino su fuerza en cuanto capaz de generar potencia y sentido, creación expresiva y comunicación fecundadora estimulante. El arte que conlleva explicación y sentido es explicación que se hace filosófica, al mismo tiempo que artística y filosoficamente penetra y aviva la fuerza germinal creadora de los vivientes, por lo que toca y descubre la naturaleza misma.

Así las cosas, si abordamos la transnaturalización desmedida de los medios tecnológicos y de comunicación, la educación artística experimenta cada día con mayor fuerza la necesidad de contar con un espacio de pensamiento y acción pedagógicas para responder a los interrogantes que se plantean desde el ámbito institucional, relativas al mejoramiento de las condiciones básicas para implementar metodologías de enseñanza y didáctica propios de la Educación Artística, y congruentes con los desafíos contemporáneos y globales. Se hace entonces indispensable, ampliar la capacidad para reflexionar la práctica artística actualizando la teoría educativa, respetando la diversidad del arte, representando el imaginario de nuestra sociedad, resguardando la memoria cultural y favoreciendo la identidad.

La educación tiene la tarea de ampliar su horizonte epistemológico e imaginativo, disponer de los saberes interdisciplinarios que estudian el iconicidad y la educación visual, y ampliar la enseñanza por medio de la imagen hacia una enseñanza de o para la imagen, evitando que sea "brutalmente normativa" como dice Mentz, y aplicadora de una simple gramá- 
tica. Al cambiar radicalmente nuestra relación con lo visible, modificamos también la forma-contenido de los objetos que producimos y/o recibimos.

La importancia del universo visual como conformador de identidades se debe no sólo a su omnipresencia, sino a su fuerte poder persuasivo: se asocia a prácticas culturales (lo que significa forman parte de lo que está pasando), se vincula a las experiencias de placer (se presenta de forma agradable, con una retórica visual y narrativa atractiva y produce satisfacción) y se relaciona con formas de socialización (los sujetos se sienten parte de un grupo con el que se identifica). Pero además el universo visual enseña a mirar y a mirarse, y ayuda a construir representaciones sobre sí mismos (la identidad) y sobre el mundo (lo que constituye la realidad).

\section{Conclusiones}

1. El arte como fenómeno estético es de utilidad práctica en la educación por prestar herramientas similares al pensamiento divergente. El arte al ser una forma de conocimiento y comunicación genera estrategias didácticas acordes con las necesitadas por la pedagogía. El arte, entonces, produce un conocimiento ligado y fiel a lo sensible; muchos aspectos de la vida no sólo requieren explicaciones sino comprensiones sentidas, imaginadas, soñadas, es decir la emergencia de un sujeto estético, lo que implica que en el proceso aprendizaje-enseñanza el arte apele y recurra a otras áreas del conocimiento; pues de lo contrario significaría una negación de un principio del pensamiento humano que es la capacidad de representación y de construcción de sentido y significado del mundo a través del pensamiento simbólico.

2. La experiencia estética se identifica con todas las formas de organización interactiva entre saberes e individuos en formación. Así, la Educación Artística se manifiesta como una necesidad para un nuevo proyecto humano, ante las insuficiencias de las que adolecen las instituciones educativas golpeadas por las crisis de la Modernidad.
Los lenguajes del arte llevados a la educación enriquecen notablemente la percepción y atestiguan los mundos posibles.

El arte posee diversas lecturas que requieren de la creación y uso de un alfabeto visual. La Educación Artística está habilitada para insertar la creatividad como método en la educación para crear lenguajes, hacer lecturas y construir alfabetos. En efecto, la Educación Artística implica una didáctica como ciencia y asignatura, puesto que se constituye en parte esencial de la pedagogía. Aquí, la Educación Artística tiene como función principal activar la sensibilidad al desarrollar capacidades sensoriales, cognitivas y representativas.

3. La Educación Artística no se trata meramente de formación y conocimiento de técnicas, obras y artistas sino que al insertarse en la vida misma concibe dentro de sí la invención de un arte para vivir; es decir, la comprensión de la historia, la estética, la ética y la organización de los procesos autoconcientes de la vida pensante.

Los enfoques pluridisciplinarios e interdisciplinarios de la investigación científica también favorecen la interrelación y la relación de saberes, lo que para el caso vendrían a ser la relación e interrelación de lenguajes artísticos para revelar la compleja integralidad del ser humano. Por ello el arte debe dejar de ser una actividad marginal para asumir un papel esencial en la educación.

En consecuencia, el arte dentro de la prácticas pedagógicas debe pasar de una semántica cognitiva a una semántica afectiva; de la construcción lógica (racionalización del mundo) a la intuición (sensorialización del mundo); de lo predictivo a la incertidumbre, al azar y a lo aleatorio; de lo pragmático y prosaico a la inutilidad de lo estético (kant). Asimismo, pasar de la información a la formación, del aprender a aprender al aprender a ser, de la imitación y reproducción a la creación, de la coacción y autoritarismo a la libertad y la expresión de la belleza. 


\section{Bibliografía}

AGUIRRE, Imanol. Teorías y prácticas en educación artística. Octaedro -EUB. Navarra, 2005

EISNER, Elliot. Educar la visión artística. Ed. Paidos. Barcelona 1998

FREEDMAN, K. "Kerry Freedman y la pedagogía estética". Pamplona. Boletín Informativo de la Universidad Pública de Navarra, Comunicaciones No. 38, 1999

FREEDMAN, KELLY.Enseñando Cultura Visual: Educación artística y la formación de Identidad. http://www.ub.es/boletineducart/boletineducart/info/freedman.htm

GADNER, Howard. Educación Artística y desarrollo humano. Ed. Paidos, Barcelona, 1989

HERNANDEZ, F. "Educación y Cultura visual". Barcelona. Octaedro. Año 2000

NOVAK, Joseph D. y GOWIN, D. Bob. Aprendiendo a Aprender, Barcelona: Ediciones Martinez Roca, SA, 1988. Fotocopias.

ORTEGA Y GASSSET, José. Ideas y Creencias. 1955. Revista Píxel- Bit.

PEREZ Ulloa, Iris. La didáctica de la educación plástica. El taller de arte en la escuela. Editorial Magisterio de Rìo de la Plata, 2002

READ, Herbert. Educación por el arte. Ediciones Paidos Ibérica, colección: Paidos Educador. Traducción de Luis Fabrlcant, primera reimpresión 1982, Barcelona

TOLSTOY, Leon. Qué es el arte? Segunda edición cibernética. Agosto del 2002 


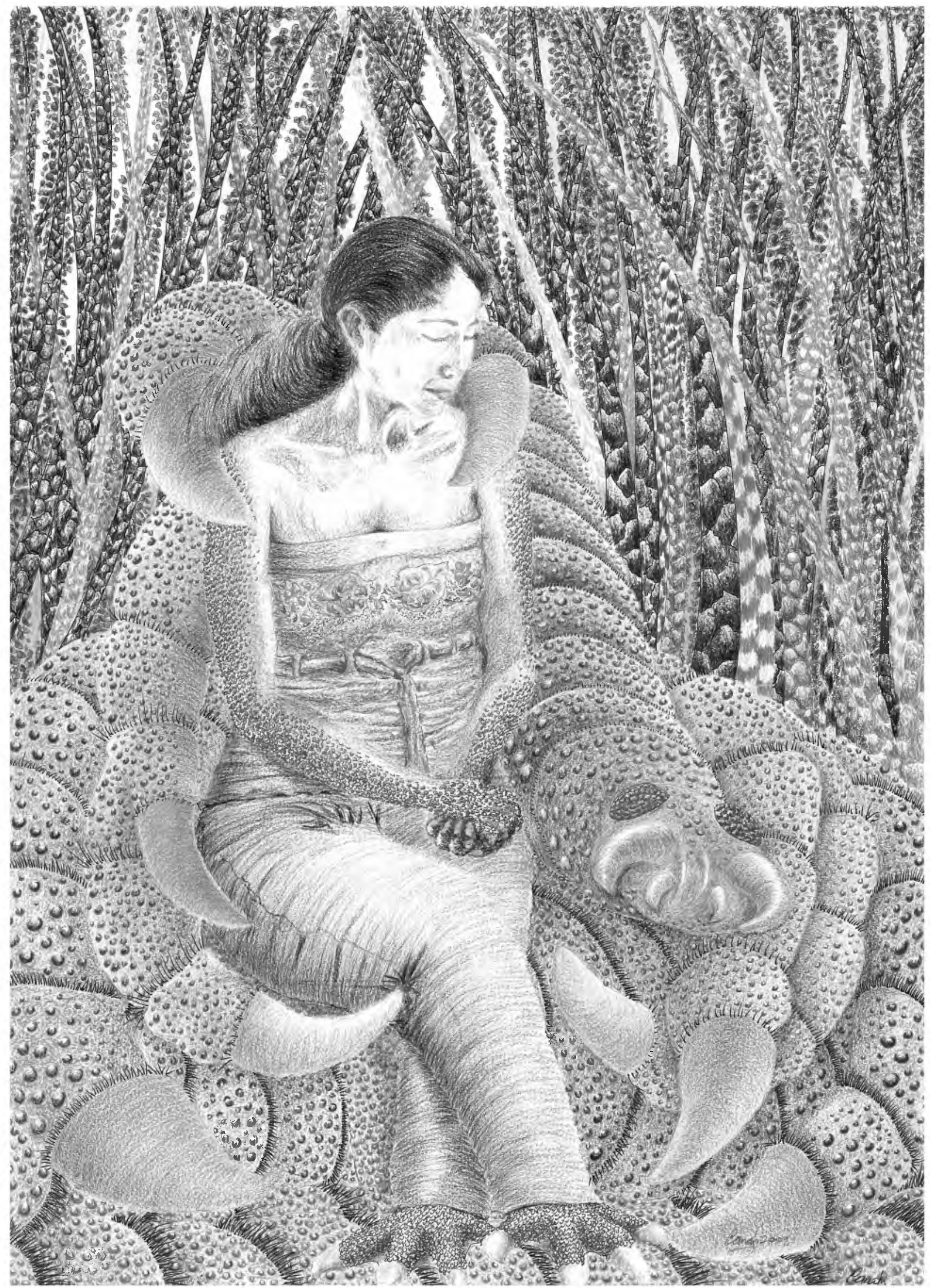

